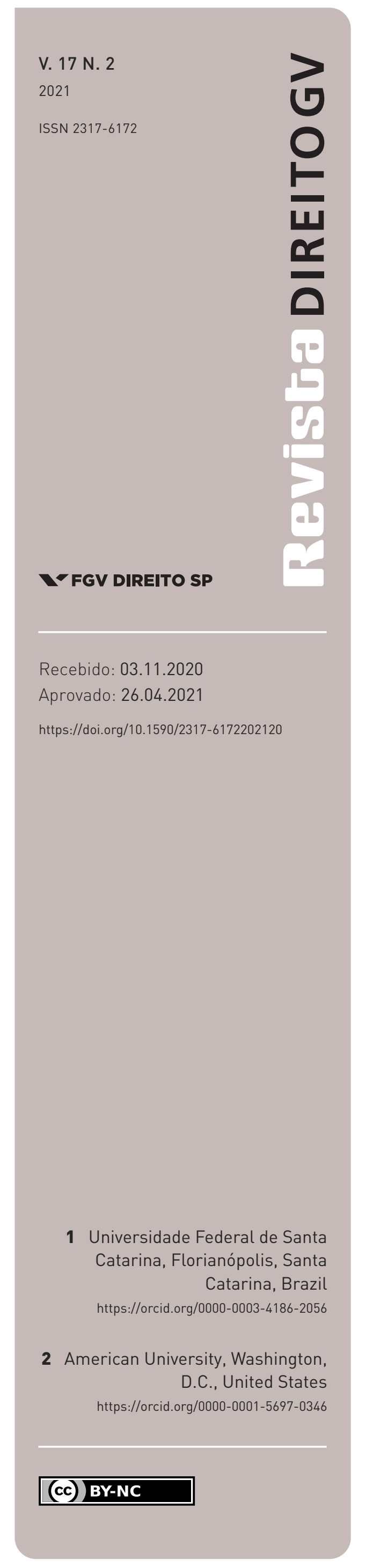

\section{Checks and Balances: The Concept and Its Implications for Corruption}

\author{
FREIOS E CONTRAPESOS: O CONCEITO E SUAS IMPLICACִÕES PARA A CORRUPCÃO
}

\author{
Luciano Da Ros and Matthew M.Taylor
}

\begin{abstract}
It is often assumed that checks and balances are effective in curbing corruption, in part because checks and balances are so often assumed to be synonymous with the separation of powers. We argue that checks and balances are only one of several potential manifestations of the separation of powers. We suggest that the apparent correlation between checks and balances and control of corruption is driven by a variety of conditions antecedent to both. Using examples from Western democracies, we demonstrate that the concept of checks and balances is by itself an empty vessel, made effective only by "hard" factors such as the balance of political forces and "soft" factors such as the adherence of elites to particular behavioral norms. This does not mean that checks and balances cannot be useful, but rather that our assumptions about their precise utility may be misinformed: the relationship between checks and balances and curbing corruption is at best indirect.
\end{abstract}

\section{Keywords}

Checks and balances; separation of powers; corruption.

\section{Resumo}

Frequentemente, presume-se que o sistema de freios e contrapesos é efetivo para conter a corrupção, em parte porque ele é tipicamente entendido como sinônimo de separação de poderes. Argumentamos que o sistema de freios e contrapesos é apenas uma das várias possíveis manifestações da separação de poderes. Sugerimos que a aparente correlação entre freios e contrapesos e o controle da corrupção decorre de condições antecedentes a ambos. Utilizando exemplos de democracias ocidentais, demonstramos que o conceito de freios e contrapesos é em si mesmo vazio, e somente é efetivado por fatores "duros", como o equilíbrio das forças políticas, e por fatores "brandos", como a aderência de elites a normas de comportamento. Isso não significa que ele não possa ser um instrumento útil, mas que nossos pressupostos a respeito de sua utilidade talvez estejam mal informados: a relação com o controle da corrupção é, no melhor dos casos, indireta.

\section{Palavras-chave}

Freios e contrapesos; separação de poderes; corrupção. 


\section{INTRODUCTION}

It is almost a truism that "checks and balances" are effective in curbing corruption. The inherent logic of this view seems to extend naturally from the basic dynamics of separation of powers: developed democracies do better in fighting corruption; developed democracies have government institutions anchored in powerful separation of powers provisions; strong and independent institutions are capable of checking and balancing each other; checks and balances curb wrongdoing by powerful elites and help move societies further down the path from particularism to ethical universalism. It helps that the concepts of checks and balances and separation of powers are buoyed by a prestigious lineage, running back through Madison, the Iroquois Confederation, Montesquieu, and Polybius, among others.

The equation of checks and balances with separation of powers is also frequent among contemporary scholars, whether in explaining broad patterns of political and economic development (ACEMOGLU and ROBINSON, 2012), anticorruption success (LEDERMAN et al., 2005), ${ }^{1}$ the essential pillars of national integrity systems (POPE, 2000), or the apparent success of specific consolidating democracies in overcoming governance challenges (MELO, PEREIRA and FIGUEIREDO, 2009; MELO and PEREIRA, 2013). Checks and balances are also often frequently invoked to justify aid programs and development initiatives pursuing cleaner government (e.g., USAID program on strengthening the judiciary in Georgia $^{2}$ or DFID "Policy Approach to Rule of Law"). ${ }^{3}$ The empirical reality apparently conforms with these perceptions: the global correlation between "constraints on government powers," which measures many conventional elements of checks and balances arising from the separation of powers, ${ }^{4}$ and "absence of corruption" in the latest edition of the World Justice Project's 2020 Rule of Law Index is a whopping 0.82.

The assumption that separation of powers equates to checks and balances, and that they have an important effect on corruption, is also propagated by some of the most influential voices in the anticorruption field. Rose-Ackerman and Palifka (2016, p. 374) summarize the causal argument: "Limits on the power of individual politicians and political institutions, accompanied by independent monitoring and enforcement organizations, can be potent anticorruption strategies that also constrain other forms of self-dealing. In a democracy, a key institution is separation of powers between the legislative and executive branches that permits

1 They argue that "Political institutions are the main exogenous force shaping the incentive structure that determines both corruption and the implementation of specific policies" (LEDERMAN et al., 2005, p. 26).

2 https://www.usaid.gov/georgia/rule-of-law.

3 https://assets.publishing.service.gov.uk/government/uploads/system/uploads/attachment_data/file/ 306396/policy-approach-rule-of-law.pdf.

4 Such as "government powers are effectively limited by the legislature" and "by the judiciary." 
each source of power to check the other.” The logic here is relatively simple, and consistent with Klitgaard's influential corruption equation (1988, p. 75): separation of powers simultaneously reduces monopoly powers and discretion by public officials, and increases their accountability, thereby contributing to limiting corruption. By fragmenting rather than unifying power, scholars claim, the "main impact of checks and balances" is "to reduce politician rents" (ACEMOGLU, ROBINSON and TORVIK, 2013, p. 847).

In sum, there is a strong consensus in the literature that checks and balances and separation of powers should be understood almost interchangeably, and that they are important tools in fighting corruption. But on closer inspection, this connection is much looser than it seems at first glance. Much of the reasoning equating checks and balances with corruption control is due to the fact that checks and balances are often understood as a synonym of separation of powers. Indeed, the two concepts often are used interchangeably, as in the quotations above. Yet, while the two terms are interrelated, they are not identical to each other (ROSE-ACKERMAN, DESIERTO and VOLOSIN, 2011). We argue that checks and balances and separation of powers are not synonyms, and that the former is a specific form of the latter: separation of powers is a broader concept that encompasses a variety of subtypes which include, but are not limited to, checks and balances.

In order to highlight the implications of this conceptual distinction, the article proposes a typology of separation of powers dynamics that situates checks and balances among other forms of separation of powers, including instances of improper and abusive checks and balances, the uses of rule of law as a political weapon, and outright impunity. Second, we argue that the apparent correlation between checks and balances and control of corruption is driven by a variety of conditions antecedent to both: the relationship between checks and balances and control of corruption is not causal, but instead one of two parallel emergent properties. Using examples from prominent Western Hemisphere democracies, we demonstrate that the concept of checks and balances is by itself an empty vessel, made effective only by "hard" factors such as the balance of political forces and "soft" factors such as the adherence of elites to particular behavioral norms and conventions. Third, because of the combination of i) a broad and often vague definition of the concept of checks and balances, and ii) the intentional exacerbation of the inherent institutional rivalries implicit to their functioning, checks and balances are often politicized and their functions distorted either in perception or in practice, or both. This does not mean that they cannot be useful tools, but rather that our assumptions about their precise utility may be misinformed: the relationship between checks and balances and curbing corruption is at best indirect, and usually quite muddied by extraneous factors.

The paper proceeds in four sections. The first describes the conceptual complexities of defining checks and balances. The second discusses the separation of powers during peak crises leading to the removal of presidents. It illustrates that not all checks imposed by legislatures on executives can be described as checks and balances proper. Instead, they might 
be considered as different types of separation of powers dynamics, some of which may not be conducive to increased corruption control. The third analyzes the potentially even more vexing issue of checks and balances in non-crisis moments, which are likely to be more consequential to curbing systemic corruption. The final section concludes.

\section{I.THE CONCEPT OF CHECKS AND BALANCES}

Can checks and balances help to control corruption by enabling legitimate forms of accountability? Democratic theory often seems to suppose they do, but there are several challenges, even when considered solely in the abstract. These challenges emerge both in the narrowest and broadest conceptions of checks and balances.

At their narrowest, checks and balances originate in the separation of powers doctrine, and in contemporary usage, the powers enunciated in the first three articles of the U.S. Constitution, splitting into three independent branches the functions associated with making, interpreting, and executing legislation. This is justified by the Madisonian notion that government be organized in such a way that "its several constituent parts may, by their mutual relations, be the means of keeping each other in their proper places" (MADISON, 1961). The justification for this separation of powers is a well-known one: "If men were angels no government would be necessary. If angels were to govern men, neither external nor internal controls on the government would be necessary. In framing a government which is to be administered by men over men, the great difficulty lies in this: you must first enable the government to control the governed; and in the next place oblige it to control itself" (Federalist 51). Secondarily, but often less emphasized, is the notion of cross-cutting cleavages that prevent infringements on the rights of the minority: "Whilst all authority in it will be derived from and dependent on the society, the society itself will be broken into so many parts, interests, and classes of citizens, that the rights of individuals, or of the minority, will be in little danger from interested combinations of the majority." Corruption, as commonly understood today, ${ }^{\mathbf{5}}$ would apparently be one such infringement. ${ }^{6}$

But even this narrow definition hides significant complexity. Existing polyarchies rely on a variety of contradictory democratic traditions, which have significant repercussions

$5 \quad$ On the evolving understanding of corruption in US law, see Teachout (2014).

6 Lest we be accused of neglect, it is worth recalling that Federalist 51 discusses the fragmentation of power not only horizontally, in terms of the separation of powers, but also vertically, following the federal principle. For reasons of length, this paper focuses solely on the horizontal aspects, although we believe extension to the vertical aspects would be relatively straightforward. 
for how they tackle corruption. O'Donnell (1998), for example, noted that polyarchies mix three partly contradictory traditions: the liberal tradition that holds certain individual rights unbreachable by the state; the republican tradition of selfless service to the public interest; and the democratic tradition of popular sovereignty. Each of these traditions suggests different institutional arrangements for solving different issues. Direct elections and the expansion of the suffrage, for instance, have been hallmarks of the democratic tradition as a way to boost responsiveness to public majorities; the liberal and republican traditions, in turn, have both suggested a sharp separation between the public and private spheres, albeit for different reasons. Whereas the liberal tradition aims to shield the private sector from undue influences by the public sphere, in the republican tradition it is the other way around. And, as it turns out, checks and balances have predominantly been designed so that they protect individual and minority rights. That is why checks and balances and separation of powers may be deemed a "liberal remedy" that has been inadvertently said to cure a "republican disease" - corruption. Unsurprisingly, the core practice of public-sector corruption - i.e., bribery - is hardly an "infringement on the rights of a minority," but largely, and especially in a democracy, an infringement on the rights of the majority who elected the officials and expect them to behave correctly (PHILP, 1997; WARREN, 2004).

The theoretical foundations of the notion that checks and balances will fight corruption are also muddied by the fact that, as Manin (1994) and Wallis (2004) note, corruption, as it was understood when the first institutional arrangements aimed at establishing checks and balances were conceived at the end of the $18^{\text {th }}$ century, was not exactly what we think of in the $21^{\text {st }}$ century, as abuse of public office for private gain. In fact, the $18^{\text {th }}$ century conception of corruption was much more a fear that the governing system might become unbalanced, allowing one branch to gain leverage over the others and ultimately deteriorate into tyrannical rule. The legislature, as the popular branch of government, was particularly feared. So, $18^{\text {th }}$ century checks and balances were designed essentially to overcome this problem of institutional primacy, not really to address what we currently consider corruption. The closest parallel to our contemporary definition of corruption was the early $19^{\text {th }}$ century fear of "systematic" corruption, whereby elites used the powers of the government to artificially create rents by limiting entry into valuable economic activities, through grants of monopoly, restrictive corporate charters, tariffs, quotas, regulations, and the like (WALLIS, 2004; see also NOVAK, 2013). But even this shifting conception of corruption, to a version closer to our contemporary definition, was only elaborated decades after the Madisonian version of checks and balances was conceived.

In its contemporary and broader usage, the concept of checks and balances often fades over into a definition that encompasses "accountability," or the notion that in a democratic society the branches of government are answerable to a variety of principals, including each other, but also often including citizens, the press, and non-governmental bodies (BOVENS, 
2007; LINDBERG, 2013; MECHKOVA, LÜRHMANN and LINDBERG, 2019). ${ }^{7}$ Of particular interest to us is "horizontal accountability," which O'Donnell $(1998,117)$ argues "depends on the existence of state agencies that are legally empowered — and factually willing and able — to take actions ranging from routine oversight to criminal sanctions or impeachment in relation to possibly unlawful actions or omissions by other agents or agencies of the state." Sometimes overlooked, as O'Donnell notes, is the fact that "these agencies can only rarely be effective in isolation. Their proceedings can move public opinion, but normally their ultimate effectiveness depends on decisions by courts (or eventually by legislatures willing to consider impeachment), especially in major cases. Effective horizontal accountability is not the product of isolated agencies, but of networks of agencies (up to and including high courts) committed to upholding the rule of law" (O'DONNELL, 1998, p. 119; MAINWARING, 2003).

In both the narrow and the broad definitions, the term "checks and balances" usually encompasses a wide range of tools such as judicial review, presidential veto, impeachment, court decisions overturning executive actions, constitutional amendments to reverse court decisions, consent of the senate on appointments and treaties, no confidence votes in parliamentary democracies, oversight hearings, congressional investigative committees, and so forth and so on. At the same time, these definitions may give us an inkling of the manifold problems of applying the concept of checks and balances and understanding its relation to corruption. Five inter-related challenges are particularly vexing:

1. The blurry lines between the branches. ${ }^{8}$ Checks and balances require the policing of the boundaries between the branches while permitting the whole of government to operate. ${ }^{9}$ To some degree, any such effort is bound to fail, in light of the fact that the three branches have attributions that transgress upon the powers of the others: although the

7 Throughout this paper, we address only democratic regimes in their relationship with corruption, following Warren (2004).

8 A simpler concern, probably best reserved for a footnote, is that there is no reason that the powers need be the conventional President-Congress-Courts. Montesquieu was thinking of monarch, parliament, courts. Brazil long subscribed to the conventional tripartite division, but with the "moderating" power of the Emperor, and later the military.

9 In American law this has led to the development of both formalist and functional legal doctrines of the separation of powers. In the formalist approach, the court seeks to draw bright lines "demarcating the three branches from each other determined by the differences between legislating, executing, and adjudicating." In the functional approach, the court considers whether the challenged action "threatens the essential attributes of the legislative, executive, or judicial function or functions" (Cornell Law School, Legal Information Institute, at https: //www.law.cornell.edu/wex/separation_of_powers). 
legislative branch holds legislative power, the executive writes decrees and the judiciary rewrites legislation through its rulings; although the executive implements the law, congress and courts influence that implementation through their vetoes and rulings; and although the courts interpret constitutionality and legality, the congress has semi-judicial powers (e.g., impeachment) and the executive controls the nomination of judges (BIRKLAND, 2001, p. 47). While such overlapping powers may assist governance because the overlap between branches ensures joint authority (MANIN, 1994), it makes our conceptual task more complex.

2. The possibility that the separation of powers established constitutionally may be undermined by the practical fusion of powers because of political parties and governing coalitions that span two or more branches of government. This is most obvious in parliamentary democracies, in which the executive is headed by a leader drawn from the legislative branch, and even more so in majoritarian or Westminster systems in which a single party controls both branches of government (LIJPHART, 1999). But it is also extremely relevant as we think about presidential and semi-presidential systems, especially that subset of regimes known as coalitional presidential systems, where a minority president is compelled to pull together a majority legislative coalition relying on a combination of executive and legislative powers. Still, even purely presidential systems are likely to see periods of cross-branch dominance: the Democratic party in the US in the 1960s, for example.

3. The fact that the actual independence of powers is extremely unlikely. As Larkins (1996, p. 618) noted with regard to judicial independence, "it is quite likely that in its pure form it does not exist anywhere. Judicial dependence, by contrast, exists in virtually every political system and is much more easily identifiable." ${ }^{10}$ Similarly, while it varies considerably over time, complete independence of the legislature from the executive is not only unlikely, but also possibly undesirable for the reason noted above: the separation of powers should not be so extreme as to halt the functioning of the whole of government.

4. The manner by which checks and balances fit into a broader regime ecology. Checks and balances are tools and the separate branches of government are empty vessels. The uses to which those tools are put, and the rulers with whom those vessels are populated, are determined by a combination of today's governing coalition, but more broadly by the longer-term regime coalition. These two coalitions are not always coincident. Dahl 
(1957, p. 293) put this point with regard to the courts: "Except for short-lived transitional periods when the old alliance is disintegrating and the new one is struggling to take control of political institutions, the Supreme Court is inevitably a part of the dominant national alliance [...]. The Supreme Court is not, however, simply an agent of the alliance. It is an essential part of the political leadership and possesses some bases of power of its own, the most important of which is the unique legitimacy attributed to its interpretations of the Constitution. This legitimacy the Court jeopardizes if it flagrantly opposes the major policies of the dominant alliance; such a course of action, as we have seen, is one in which the Court will not normally be tempted to engage." Further, we must surrender sentimental idealism: no matter how deep the disputes between today's governing coalition and the opposition, the overall regime coalition may still act as a cohesive force - or as an "elite cartel," as suggested by Johnston (2005) - against the use of checks and balances. As Mazzuca (2010, p. 342) has argued with reference to Latin American democracies, there is no a priori reason to assume that a regime coalition that favors the democratic process for accessing power will necessarily also be eager to strengthen the checks and balances over the exercise of that power, especially if that means surrendering long-anticipated fruits of patronage and clientelism (on this point, see also ACEMOGLU and ROBINSON, 2006 and 2012).

5. The fact that some of what we frequently refer to as checks and balances, at least the kind that seem most related to corruption, often are internecine, arising from within the same branch they target. Inspectors general within an agency, federal investigators targeting other agencies of the executive branch, internal affairs (corregedorias) within the courts, or congressional ethics committees that investigate their own members are often engaged in work that provides a form of accountability, without necessarily having a strong component of separation of powers interaction beyond occasional public support from the other branches.

All of these challenges raise generic doubts about the extent to which government officials are likely to check each other, comply with other branches' decisions, or perhaps most importantly, effectively utilize the tools of checks and balances at all, at least in the manner that we conventionally think that separation of powers leads to checks and balances. This suggests that we need to go beyond a strictly formalistic approach to law and corruption, whereby the mere presence of separation of powers arrangements in a written document such as a constitution would automatically translate into the existence of checks and balances. Instead, it may be more promising both to situate checks and balances proper within other separation of powers dynamics and to understand how such an arrangement interacts with the broader political ecology in which it operates to actually alter corruption control. These are the tasks of the next two sections. 


\section{CHECKS AND BALANCES IN PEAK CRISES}

Apart from the vagueness of the use of the concept of checks and balances, a second set of problems is highlighted by the actual functioning of checks and balances in moments of direct interbranch conflict. The trouble here is that even in Madison's conception, the checks and balances "game" is designed to be predominantly political - ambition counteracting ambition - and these critical moments are therefore often brawling contests between political brutes who have no compunction to stick too closely to anything resembling objective truth or the rule of law. The exercise of judging whether checks and balances are functioning properly or improperly is thus often an exercise in moral relativity.

Rather than engage in such a subjective effort, we seek conceptual clarification and, to some extent, concept-building in the tradition of Sartori (1970). ${ }^{11}$ We dispute the assumption that separation of powers and checks and balances are synonyms. In order to avoid the common conflation between the two terms, we suggest that the latter is a specific form of the former, alongside other types of interbranch dynamics. Said another way, checks and balances are only one possible outcome of separation of powers. Our classification is thus an attempt at establishing clearer criteria to identify and discern cases of checks and balances proper from seemingly similar phenomena also arising from the workings of separation of powers in existing democracies.

To this end, Helmke (2017, p. 51) offers a starting point to understand the difficulties involved in interpreting if and when checks and balances are in place, noting that there are at least two distinct conditions that influence the degree to which checks and balances can be said to be functioning:

i) There is a clear and serious violation of the law; and

ii) Formal rules delivering punishment are properly followed.

Both conditions must be met before concluding that checks and balances are working as designed. When only one of them is present but not the other, or when both are absent, separation of powers is not expected to lead to checks and balances, but to other forms of interbranch dynamics. These various combinations are readily visible in the recent history of American democracies, as shown in Table 1.

Focusing on impeachment and similar instances of presidential removal allows us to discuss these issues in moments of high relief, referred to here as "peak crises." Of course, this

11 This tradition of concept-building represented by Sartori (1970) emphasizes well-defined, mutually exclusive and jointly exhaustive definitions based on necessary criteria. It contrasts especially with other forms of concept-building, such as "family resemblances" and "radial concepts" (COLLIER and MAHON Jr., 1993). 
is a limited approach, as it focuses only on interbranch dynamics that are characteristic of presidential systems. However, as we discuss later in this section, the typology can be expanded both to other branches of government (including anticorruption actions taken by the judiciary and prosecution services, for instance) and to other governing arrangements, such as parliamentary systems. Presidential impeachments, in other words, offer us a way to illustrate the classification of interbranch dynamics using highly visible and identifiable cases that, given their well-known nature, can be described succinctly rather than requiring extensive detail. ${ }^{12}$ Lastly, such cases offer us an opportunity to discuss our classification precisely within the institutional settings where checks and balances were arguably first designed (the US constitution) or which have been directly inspired by the US constitution (the case of presidential Latin American constitutions): systems of tripartite division of powers that are characteristic of presidential, rather than parliamentary systems.

Table 1 splits Helmke's binary second condition into three possible outcomes: the first one when formal rules delivering punishment have been followed properly; the second one when formal rules have been followed improperly; and the third one when formal rules have not been initiated or followed through. This leads to six possible "separation of powers dynamics" in peak crises, which should be understood primarily as ideal types. This brief exercise reveals that not all forms of punishment - or lack thereof - fit clearly into the definition of checks and balances provided above. As it turns out, most forms of separation of powers dynamics in peak crises may be better classified not as checks and balances proper, but as other interbranch dynamics.

In fact, only Cell I clearly displays cases that meet the criteria that allow us to identify when checks and balances can be said to be in place: a clear and serious rule violation is found and it is adequately punished. We will discuss this criterion later, but for now suffice it to say that even in these most clear-cut of cases, there is some ambiguity about the extent to which the violation was truly "punished." In the US case, the impeachment of former president Richard Nixon (1969-1974) was occasioned by fairly blatant evidence of a serious violation, but the process was interrupted before its termination by his resignation, and Nixon was subsequently pardoned. Similarly, the impeachment of Donald Trump (20172021 ) for abuse of power and obstruction of justice in soliciting foreign assistance in the 2020 election clearly fits the criteria of a grave violation. His impeachment in the House followed procedure and imposed a reputational sanction, making him only the third president in history to suffer that fate. But Trump was subsequently acquitted in a near party-line

12 Because we are building this classification based on such notorious cases, these cases are not "tests" in any meaningful sense, as one cannot test an argument based on the data that has been used to develop it in the first place. 
vote in the Senate. The impeachment of Fernando Collor (1990-1992) in Brazil for corruption went further than either US case, with impeachment in the lower house and removal by the Senate. ${ }^{13}$ Even in this case, however, there was some ambiguity added to the case when the high court later voted not to convict Collor after his removal from office - even though the courts did convict the other individuals involved in the so-called "PC Farias" corruption scandal that ultimately led to his impeachment. So, it seems that even in the straightforward cases, nothing is as clear-cut as our high-school social science teachers or law books supposed.

TABLE 1 - SEPARATION OF POWERS DYNAMICS IN PEAK CRISES

CLEAR AND SERIOUS VIOLATION

OF THE LAW

I. CHECKS AND BALANCES

US: NIXON (1974)

US: TRUMP (2020, ELECTION)

BRAZIL: COLLOR (1992)

FORMAL PROCEDURES

VIOLATION PUNISHED
III. IMPROPER CHECKS AND BALANCES

PARAGUAY: LUGO (2012)
UNCLEAR AND MINOR VIOLATION OF THE LAW

II. WEAPONIZED CHECKS AND BALANCES

US: CLINTON (1999)

BRAZIL: ROUSSEFF (2016)

IV. ABUSIVE CHECKS AND BALANCES

HONDURAS: ZELAYA (2009)

IMPROPERLY FOLLOWED

AND VIOLATION PUNISHED

NO FORMAL PROCEDURES

V. IMPUNITIVE CHECKS AND BALANCES

INITIATED OR FOLLOWED THROUGH BRAZIL: TEMER (2017-2018)

VI. INDETERMINATE CHECKS AND BALANCES

US: TRUMP $(2020$, COVID-19)

Source: Authors.

In turn, Cell II refers to cases where the rule of law is used "as a political weapon" (MARAVALL, 2003). While the procedural niceties of presidential removal are followed, the underlying violations may not rise to a commonly accorded standard of impeachment. The problem of course is that this standard is typically a subjective political judgement call. Two examples illustrate the point: the impeachment of Bill Clinton (1993-2001) in the US for lying about an extramarital affair; and of Dilma Rousseff (2011-2016) in Brazil for engaging

13 After having been temporarily removed from office by the Chamber of Deputies in October 1992, Fernando Collor resigned from office when the Senate started to vote for his impeachment in December 1992. The Senate considered it a "late" resignation and impeached him in the following day, in a nearly consensual vote (SALLUM Jr., 2015). 
in fiscal sleight of hand that, while more pronounced than under any of her predecessors, merely replicated longstanding practice. In both cases, the technical violation of the law was never really disputed, but the impeachment itself was seen by legal experts and a significant portion of the population as disproportionate to such minor offenses. Indeed, as Sunstein (1998) suggests, possibly only grave violations should be the basis for presidential impeachments, given their extremely destabilizing consequences. Of course, these cases demonstrate the fuzziness of the lines between our categories: supporters of impeachment may be heard repeating the mantra that the "law is the law," offering the possibility that the impeachment should really be a Cell I episode; defenders of the president, meanwhile, will argue that because the punishment far exceeds the crime, formal procedures are not being followed, and the impeachment is really an abusive break with institutional norms, a "parliamentary coup" or a "soft coup," belonging in Cell IV. ${ }^{14}$

Cells III and IV offer examples of improper procedures that deliver punishments. As such, they represent a breach of the liberal tradition that holds that due process is an integral part of the rule of law. In the third cell, formal procedures were improperly followed in the face of a clear and serious violation. The case of former Paraguayan president Fernando Lugo (2008-2012) is illustrative: impeachment was justified by the deaths of 17 police and farmers in a conflict resulting from the heavy-handed attempted eviction of settlers from rural lands owned by a powerful former politician. The violation was serious and relatively clear, ${ }^{15}$ Lugo was removed from office by overwhelming majorities (only 1 in 80 deputies and 4 of 45 senators voted against impeachment), and even the courts upheld his removal. Yet he was given only two hours to prepare his defense in the trial and the overall speed of the process - begun in Congress on June 21 and upheld by the court four days later - was unseemly, leading to condemnation from the Inter-American Commission on Human Rights and Paraguay's suspension from Mercosur.

Cell IV has long been a staple of democratic upheaval in the Americas, although it increasingly appears under a new guise during the third wave of democracy. The removal of Manuel Zelaya (2006-2009) from office in Honduras offers an example. Zelaya sought changes to the constitution, including introduction of the possibility of reelection; he called a non-binding referendum on whether to call a constituent assembly; he ignored a Supreme Court decision to desist; on the morning of the scheduled referendum, the military seized him and flew him to Costa Rica; and Congress then voted him out of office. No party was entirely in the right in this case, but there was clearly a short-circuiting of democratic process in Zelaya's removal

14 For a discerning analysis of the growth in the use of the term "coup d'état" or "golpe" at a time when the actual incidence of coups has been declining in Latin America, see Marsteintredet and Malamud (2019).

15 Although Congress also added less clear-cut allegations to the impeachment bill. 
that deserves the label "abusive checks and balances."16 Under the third wave of democracy, such unconstitutional interruptions have often been cloaked in democratic language and procedure rather than imposed by militaries or strongmen. Partly in consequence, they can be difficult to unambiguously label unconstitutional, even when they are.

The last row includes cases in which separation of powers does not lead to the initiation of formal procedures or, even if these were initiated, they were not followed through, contributing either to failure to punish a clear violation of the law or to an indeterminate state in which it may never be clear whether there was an actual serious violation. An example of Cell $\mathrm{V}$ and the impunity by which it is characterized comes from the case of Michel Temer (20162018) in Brazil. In 2017, a wiretapped conversation between Temer and a meatpacking tycoon caught the two discussing the exchange of bribes for lax regulatory oversight and to obstruct justice by buying the silence of a former speaker of the house who had been arrested earlier that year. The Prosecutor-General pressed criminal charges against Temer, and street protests demanded Temer's removal, but Congress - many of whose members were also being targeted in corruption probes - on two occasions failed to approve the initiation of an impeachment process, essentially providing Temer with blanket immunity only one year after they had impeached his predecessor on much more trifling legal grounds.

Finally, Cell VI is an indeterminate one: it is impossible to know whether checks and balances are working or failing. This cell is indeterminate because there are two possibilities. On the one hand, it is possible that checks and balances are working just as the democratic ideal would have it: there is no indication of a serious violation and therefore no reason to initiate proceedings. It may even be that the simple threat of formal procedures like impeachment may be working to deter wrongdoing, an ideal state in which the mere threat of checks and balances inhibits the behavior that would trigger their use (HELMKE, 2017). On the other hand, consider the reaction to Donald Trump's public boast in June 2020 that he had slowed down the testing of patients for Covid-19. If true, this would very much possibly be a "high crime and misdemeanor," a case of risking American lives for political gain. The claim could also be false, of course: nothing but a bit of calculated drama from a master of political high-wire acts. But the passivity of House members who might otherwise initiate an investigation - whether motivated by the proximity of elections, the lackluster results of another impeachment effort five months prior, or the pandemic of the moment - means that Americans will never know where the truth in fact lay, or whether checks and balances should have been mobilized to greater effect. Here, the difficulty in classifying the absence of formal procedures as either checks and balances working properly or failing miserably, of course, follows from the fact that both are instances of a 
"non-decision" which, "by definition, is a nonevent, it is not observable" (BACHRACH and BARATZ, 1963, p. 641).

What quickly becomes apparent from the table is the extent to which the correctness of these six separations of powers dynamics is open to debate. As a consequence of that ambiguity, the process of moving from an allegation of serious wrongdoing to an effective and legitimate sanction is far less straightforward than simply identifying the problem and remedying it. In the Madisonian approach to separation of powers, politics and the political context make ambition check ambition, but this table illustrates that ambition may also lead to either excessive aggression or excessive timidity. Accordingly, one of the main takeaways from the classification is that even the enforcement of a grave sanction such as impeaching the president may ultimately undermine, rather than strengthen, anticorruption efforts. Seen jointly, the cases of presidents Rousseff and Temer in Brazil - in which the latter, accused of serious irregularities, was able to escape removal from office, while the former had been impeached on more dubious grounds just a year earlier - illustrate the point. At the same time, the classification also suggests that not all presidential impeachments are abusive or destabilizing; some are indeed cases of checks and balances in accordance with our classification (PÉREZ-LIÑÁN, 2007).

The brief empirical cases support the claim that in peak crisis situations separation of powers dynamics are inherently political processes which only under certain circumstances generate checks and balances that curb presidential power. This should not be at all surprising. Still, the fact that presidential impeachments are political processes does not preclude them from leading to legally sound results or to generating legitimate accountability and corruption control. We should be cautious about holding a firm belief about any sharp dichotomy between law and politics here, as the former - and particularly public law - is often a product of the latter. Court rulings in salient corruption cases may be just as political as impeachments, as more than half a century of judicial politics research suggests. ${ }^{17}$

17 It is difficult to imagine a methodological solution that would provide a clearly objective manner of evaluating whether the process and the violation of law have been properly classified in separation of powers dynamics. In judicial cases, instead of using judicial decisions as criteria to assess whether or not checks and balances are in place (or, more to the point, if rule of law violations are relatively clear or not, and if procedures have been adequately followed or not), one alternative approach is to rely on expert opinions from constitutional scholars not involved in the cases under examination. Kapiszewski (2011), for example, surveyed legal experts in Brazil to identify Supreme Court rulings considered politically salient and to understand their respective motivations. In fact, whereas some of the decisions she examined can be said to be "principled," others do not fit that pattern so easily, being labelled "pragmatic," "deferential," "protective" or "support-building." A similar analytical strategy could be deployed in the analysis of impeachments and presidential removal cases. 
The classification shown in Table 1 can also be applied to other separation of power dynamics related to corruption control. One common dynamic relates to court rulings in cases of wrongdoing by public officials. The literature on the "judicial politics of corruption" offers many cases that could be examined along the lines of our typology (DA ROS, 2014). ${ }^{18}$ Suffice it to say here that even if the courts adequately follow procedure, but ultimately fail to punish clear violations of the law, these may not be, strictly speaking, instances of checks and balances. Recent scandals in Brazil that have been dismissed by the judiciary on debatable procedural grounds, such as Operação Castelo de Areia of 2009, illustrate the point: these judicial decisions seem to have been premised on strategic concerns about the potential conflict that might emerge with the elected branches of government, rather than more straightforward legal considerations. Similarly, courts that haphazardly punish wrongdoing may not be clear-cut examples of checks and balances, instead reflecting the improper or abusive forms in Cells III and IV. In fact, much of the criticism of the Lava Jato investigation in Brazil is premised precisely on the charge that it was an improper or abusive form of checks and balances, rather than on a claim that the violations were not serious or clear. Beyond Brazil, Cell II captures most forms of "lawfare," and Cells III and IV may apply to numerous anticorruption "clean-ups" by semi-authoritarian and hybrid regimes.

Whether or not the sweet spot of legitimate accountability is found will depend to a great degree, therefore, on the overall regime ecology, which precedes the institution of checks and balances proper. This is quite different from the assumed logic of much of the literature, which supposes that institutions such as separation of powers necessarily curb abuse by themselves and automatically spawn effective checks and balances. If there is this much controversy about the legitimacy of checks and balances when they play out in moments of peak institutional crisis, what is the likelihood that checks and balances will be effective in curbing wrongdoing when the public and politicians are paying less attention?

\section{DAY-TO-DAY CHECKS AND BALANCES}

Most of the time, of course, checks and balances are much more routine, and therefore subtler, than those described in the previous section. In an ideal world, when these checks

Apart from broader studies that assess the impact of judicial independence on corruption (RÍOS-FIGUEROA, 2012), the literature on the "judicial politics of corruption" encompasses phenomenon as varied as the role of different judicial selection rules in US state supreme courts (ALT and LASSEN, 2008), the international networks built by Western European judges (SIMS, 2011), the politicization of prosecutions in Mexican states (ANG, 2017), grandiose events such as the Mani Pulite investigation in Italy and the Lava Jato investigation in Brazil (DELLA PORTA, 2001; LAGUNES and SVEJNAR, 2020), the rising prosecution of corruption cases in Eastern European nations (POPOVA and POST, 2018), and cases of anticorruption judicial specialization in countries such as Indonesia and the Philippines (BUTT and SCHÜTTE, 2014; PANGALANGAN, 2010), among numerous others. 
and balances are functioning - especially with regard to the control of corruption - the following conditions would prevail:

: Violations are rare because they are cut in the bud, before they occur, by agents who either know that they are under the vigilant eye of other branches, or better yet have simply inculcated appropriate norms of behavior;

: There is oversight, but it is not so great as to completely immobilize government;

: Violations are uncovered and punished in a timely and proportional fashion by networks or webs of accountability agencies;

: Oversight agencies behave with equanimity, treating offenses equally without regard to the targets' personal or partisan characteristics, and recognizing that not all violations require heavy-handed interventions;

: There is coherence to the actions of the overall web of accountability, with clear-cut responsibilities and corresponding coordination across agencies; and

: Agencies have neither excessive dependence on, nor excessive independence from, their political principals.

Departures from this ideal are of course constant, even in democracies that we consider highly functioning. In part, this is because the concept of checks and balances relies on counteracting ambitions, a form of politicization that by its very nature introduces incentive structures that may cut against the ideal conditions noted above. Said another way, when the branches are set against each other, they will each have an incentive to strategically shape the other, to work to blunt the other's destructive potential, to place or recruit allies in the other, and to otherwise push the other branches not to check or balance, but instead to support and buttress.

This brings us to a particularly salient issue: the proper functioning of checks and balances is determined by how the empty vessels of the branches are populated by members of the governing coalition of today and by the longer-term regime coalition. The regime ecology that determines whether checks and balances function in ways that approximate the ideal has an independent effect on the control of corruption.

The starting point for this discussion is the frequent observation that just as important as the institutional checks themselves are the partisan players who inhabit these checks. As Heller, Kyriacou and Roca-Sagalés point out in a study of legislative checks: "when institutions are controlled by rivals (i.e., when they effectively comprise partisan checks), veto players check each other; when institutions are controlled by allies, by contrast, veto players collude". ${ }^{19}$ We would take one step further, noting that partisanship is not always the only explanation of the effec- 
tiveness of formal checks: membership in the regime coalition may be as important, and perhaps more important, than partisanship, given that regime members' attitudes about corruption are frequently shaped by shared understandings of "how the game is played".

Regardless of whether we focus on membership in the regime coalition or in particular parties, it is evident that institutional checks and balances are a mediating variable between the regime ecology and control of corruption (Figure 1). ${ }^{20}$ This means that the effect of checks and balances may either swamp the effect of the regime ecology or boost it, as shown in the fictitious numerical examples on the north and south of Figure 1's lines. In the first and more desirable case, depicted north of the line, the regime ecology contributes a factor of 1 to checks and balances and a factor of 1 to control of corruption. The natural wobbliness of checks and balances, however, means that only some smaller portion, say 60\%, of the regime ecology's potential positive impact is transferred through checks and balances to the control of corruption, for a net total impact of 1.6. In the second case, a much weaker regime ecology is only able to transfer a factor of 0.5 directly to control of corruption, for reasons discussed below. Furthermore, not only do checks and balances not function as designed, but they in fact undermine control of corruption, perhaps because of collusion within the regime coalition. The examples of the Rousseff and Temer cases described in the previous section are apropos: in Rousseff's case, the governing coalition felt threatened by anticorruption investigations and Rousseff did not give credible signs that she could effectively control the investigators (most of whom were located within her executive branch). Partly in consequence, the coalition impeached the president on relatively dubious grounds. When, by contrast, oversight agencies found even more compelling evidence of wrongdoing by Rousseff's successor Temer, checks and balances not only did not work, but instead protected Temer, who proceeded to undermine control of corruption even further. The net effect in this case would be -0.5 , resulting from the weakly positive direct effect of the regime ecology on control of corruption, as well as the negative effect of poorly functioning checks and balances, which in fact reduced the net control of corruption.

authors like Tsebelis assume that if co-partisans control institutions, their preferences are "absorbed," a practice which "ignores a lot of interesting action”. More generally, Dahl (1956, p. 83) claimed over half a century ago: "Because we are taught to believe in the necessity of constitutional checks and balances, we place little faith in social checks and balances. We admire the efficacy of constitutional separation of powers in curbing majorities and minorities, but we often ignore the importance of the restraints imposed by social separation of powers".

20 A mediating variable lies between an independent variable and the dependent variable: some of the effect of the independent variable passes through the mediating variable to the dependent variable (BARON and KENNY, 1986, p. 1176; IMAI et al., 2011). 
Figure 1 - CHECKS AND BALANCES AS A MEDIATING VARIABLE

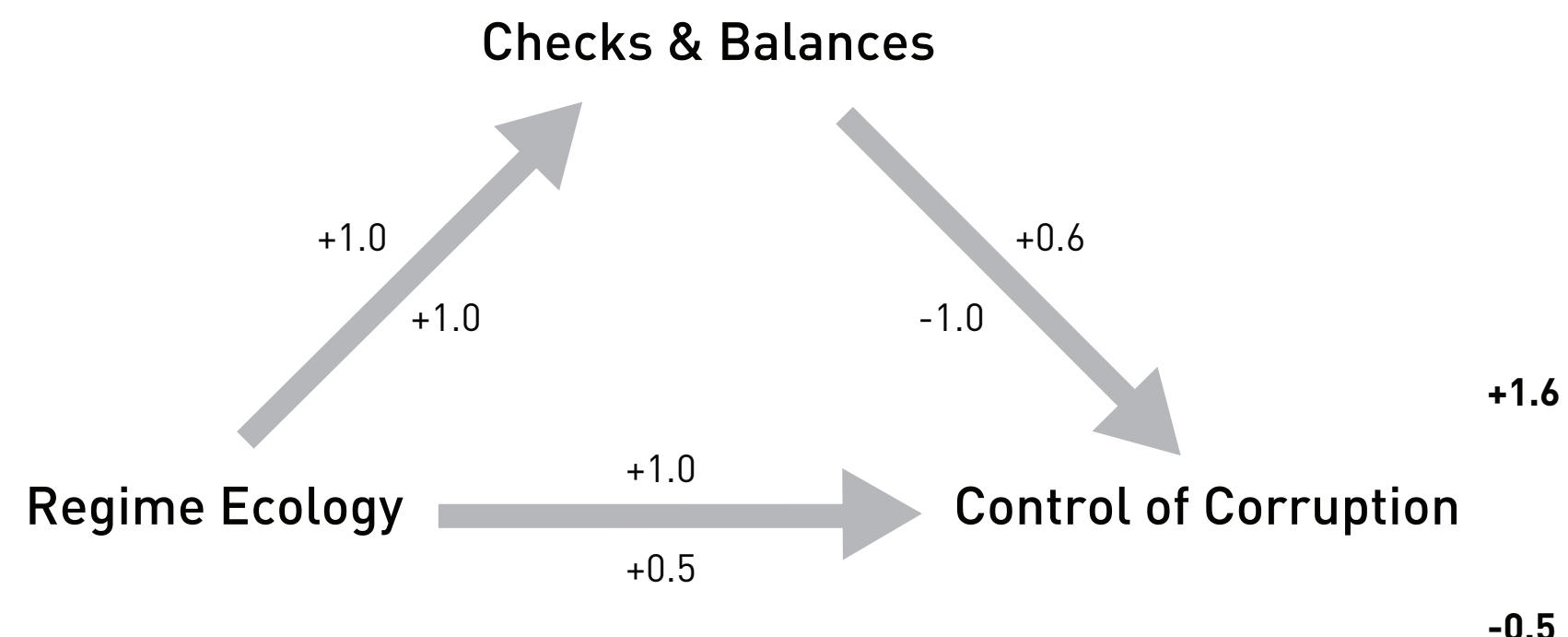

Two questions arise from Figure $1 .{ }^{21}$ First, what is the regime ecology, and what determines its effect on both control of corruption and checks and balances? Second, how does regime ecology determine the mediating effect of checks and balances?

Regime ecology has three dimensions: economic and political dominance, citizen engagement, and state capacity (DA ROS and TAYLOR, forthcoming). These three dimensions are not independent of each other. Differing combinations of the three lead to different strengths and distinct pathologies, but for now suffice it to define each of the components in turn, addressing their effect on control of corruption and the likelihood that checks and balances will be utilized effectively.

Economic and political dominance, at its extreme, is inimical to any sort of control of corruption: the concentration of power eliminates any distinction between public and private. Ipso facto, dominance can never be complete in democracies. Nor is it likely that economic and political elites will overlap completely in democracies: as Madison (1961) noted, the "many parts, interests, and classes of citizens" help to ensure that there is never complete dominance. Yet quite frequently, the governing coalition controls two or more of the branches of government. This can have the effect of diluting the ideal functioning of checks and balances, as seen in several examples in the previous section. Somewhat less frequently, but not infrequently, the regime coalition acts in concert to block changes to the regime - such as judicial, political, or electoral reforms - that might improve the control of corruption.

21 For purposes of clarity, Figure 1 focuses only on the demand side for corruption: that is, the provision of control of corruption. To complicate matters further we could imagine another similar figure that looked at the supply side: that is, the structure of the provision of public goods, which is also determined by political institutions such as checks and balances (LEDERMAN, LOAYZA and SOARES, 2005). 
Regime type, coalitional necessity, party system fragmentation, and electoral rules all influence the conditions of dominance, although the effects of such institutions are not at all clearcut, in part because the multiplicity of combinations makes it quite difficult for scholars to distinguish, say, the independent effects of differing electoral rules. ${ }^{22}$ Equally important is the fact that the willingness of rivals to collude may depend as much on informal rules about the use of patronage to construct a coalition as on the formal rules about how elections are run.

Brazil offers a particularly intriguing example of the effect of dominance on the use of checks and balances and on the control of corruption. It has been common to discuss politics in democratic Brazil as a bipolar contest between Cardoso's PSDB and Lula's PT, the two parties that held the presidency for more than two decades between 1994 and 2016. But Brazil has been governed by a coalitional presidential system centered around a minority president, and the presidential party since 1990 has never held more than one-fifth of the seats in Congress (AMORIM NETO, 2018). This has the effect of forcing the president to pull together a legislative coalition from among nearly three dozen political parties, using the toolkit of legislative and budgetary powers (CHAISTY, CHEESEMAN and POWER, 2018). Over the last 35 years of democracy in Brazil, one party has been particularly important in this process, establishing the norms of political exchange and elaborating diverse stratagems for sharing power: the MDB.

TABle 2 - PoWer YeArs Of PARTIES IN BRAZILIAN EXECUTIVE AND LEGiSLATIVE BRANCHES, I985-2020

\begin{tabular}{lllllll}
$\begin{array}{l}\text { POLITICAL } \\
\text { PARTY }\end{array}$ & PRESIDENCY & $\begin{array}{l}\text { CABINET } \\
\text { PARTICIPATION }\end{array}$ & $\begin{array}{l}\text { SENATE } \\
\text { PRESIDENT }\end{array}$ & $\begin{array}{l}\text { CHAMBER } \\
\text { PRESIDENT }\end{array}$ & $\begin{array}{l}\text { POWER } \\
\text { YEARS }\end{array}$ & $\begin{array}{l}\text { PERCENTAGE } \\
\text { OF TOTAL }\end{array}$ \\
\hline MDB & 9.5 & 30 & 30 & 17 & 86.5 & $41 \%$ \\
\hline PT & 13.5 & 13.5 & 0 & 6 & 33 & $15 \%$ \\
\hline DEM & 0 & 19 & 5 & 8 & 32 & $15 \%$ \\
\hline PSDB & 8 & 15 & 0 & 2 & 25 & $12 \%$ \\
\hline PP & 0 & 21 & 0 & 0.5 & 21.5 & $10 \%$ \\
\hline PTB & 0 & 15.5 & 0 & 0 & 15.5 & $7 \%$
\end{tabular}

Source: Authors.

22 As Heller, Kyriacou and Roca-Sagalés (2016) note, even on the "simple" issue of plurality or majoritarian electoral rules and district magnitude, scholars such as Persson, Roland and Tabellini (2003) and Chang and Golden (2006) come to differing conclusions about the impact on corruption. 
As Table 2 demonstrates, in the 35-year period from 1985 until 2020, the MDB was the central member of the governing coalition, holding key positions in the executive branch for nearly 90\% of the period (AMORIM NETO, 2018, 303-305). ${ }^{\mathbf{2 3}}$ Its influence also extended to Congress. The MDB held the presidency of the Senate during all but five years (neither the PT nor the PSDB ever held the position) ${ }^{\mathbf{2 4}}$ and the presidency of the Brazilian lower house (Câmara dos Deputados) for 17 of the 35 years. ${ }^{25}$ Lastly, the MDB held the Brazilian presidency three times, even though it was never directly elected to the position. ${ }^{26}$ The runner-up party, the PFL (later renamed DEM) never held the presidency, but it was second only to the MDB in terms of its control of the Chamber and Senate, and ahead of both PT and PSDB.

The dominance of these core coalition members in the elected branches of government carried over into semi-judicial and judicial institutions. Indeed, it would be surprising if it had not. The top ranks of the accounting oversight body, the TCU, for example, were filled by retiring politicians; none of these were PSDB or PT members, but instead all drawn from the MDB and other parties of what is known in Brazil as the "Centrão", the transactional coalition allies who have been the fundamental core of the regime coalition since 1985. In the courts themselves, the Brazilian judiciary follows institutional rules that curb the most extreme partisanship in nominations to judgeships. But at the apex of the system, the Supreme Federal Tribunal (Supremo Tribunal Federal, STF) has acted as a member of the regime coalition, preserving most politicians from accountability, protecting elite privileges, curbing efforts to contest the constitutionality of controversial policies (often in the name of regime stability), and otherwise ensuring that the federal elected branches are only occasionally checked (KAPISZEWSKI, 2011; DA ROS and INGRAM 2018). Indeed, any

23 During the Collor administration (from late 1990 until late 1992), the first year of Lula da Silva's presidency (2003-2004), and so far in Bolsonaro's administration.

24 The 1997-2001 period, when Senator Antônio Carlos Magalhães (of PFL) held the position, and since Feb 2019, when Davi Alcolumbre (also of PFL/DEM) held the post. We have excluded from this calculation interim presidencies. There were two in the 1985-2018 period: Edison Lobão (then of the PFL, later MDB) was interim president of the Brazilian Senate for one day in September 2001, and Tião Viana (of PT) held the position for two months in late 2007. Source: https://www25.senado.leg.br/web/senadores/novarepublica, accessed on May 26, 2020.

25 Source: https://www2.camara.leg.br/a-camara/conheca/historia/Ex_presidentesCD_Republica, accessed on May 26, 2020.

Instead, an MDB vice-president took office in 1985 (Sarney), 1992 (Franco) and 2016 (Temer) after the president was incapacitated (Tancredo Neves, who passed away in 1985 before taking office) or impeached (Fernando Collor de Melo and Dilma Rousseff). Importantly, the first two were not members of the MDB when they were serving as vice-presidents, but became members once they took office or just prior. 
checking by the STF seems to occur more frequently at the level of subnational governments, privileging the federal government against states and municipalities (OLIVEIRA, 2009). It is hardly coincidental that the Senate, which vets all appointees to the STF, has never had a serious debate or split over nominations to the court, suggesting that these appointees are largely seen as unthreatening to the regime coalition. In fact, in judicial appointments, presidential anticipation of coalition preferences is much more common than presidential imposition of the chief executive's preferences (LLANOS and LEMOS, 2013).

An even more pronounced example of this phenomenon is apparent in Argentina, where the partisan affiliations of legislators and the formal structure of institutional checks and balances had little effect during the Kirchner administrations. As Manzetti (2014) has shown, the dependence of legislators on provincial governors and party bosses, the reliance of governors on federal transfers, low reelection rates and correspondingly low levels of legislative expertise, presidential decree powers that hollow out legislative checks, weak executive adherence to legislative summons, and a dependent judiciary all emasculated the expected functioning of checks and balances.

A second dimension of the regime ecology has to do with civic engagement, particularly by non-governmental bodies, such as media, civil society organizations and the public more broadly. Without such engagement, it is hard to imagine checks and balances functioning at all: think Watergate without Bernstein and Woodward, the impeachment hearings against Nixon without the public uproar occasioned by the Saturday night massacre, or Collor or Rousseff's impeachments without nationwide protests (PÉREZ-LIÑÁN, 2007). Such engagement helps to define where the limits of tolerance lie, establishes the collective norms that are at stake, and indeed establishes the conditions that political actors respond to as they seek to fulfill their ambitions.

That is not to say that such engagement is always, or even usually, a burst of Putnamesque democratic civic virtue. Indeed, the baying hounds of the press corps and the irrational crowd may often have consequences that either end positively, but only after ugly episodes (e.g., the noxious nativist sentiments that contributed to Progressive Era reforms in the US; Hofstadter 1966), or simply end poorly (e.g., civil society engagement in the Weimar Republic; Berman 1997). A related issue is that the public is unfortunately not very good at reliably understanding if democratic procedures are functioning, or interpreting events in a nuanced and complex manner. In Rousseff's impeachment, for example, a high proportion of Brazilians were convinced that her removal was associated with corruption; and further, that addressing that corruption would help address the economic crisis. In other words, their participation in protests was mobilized around dubious pretenses.

These caveats aside, the point is that engagement by people and organizations outside the formal institutions of government shapes how those institutions function. Public engagement and opprobrium often put up the back of otherwise supine politicians, either by helping them to rediscover their moral compass, or by providing opportunities for them to advance their 
ambitions. And they may prove the last bastion of accountability: the media, as McMillan and Zoido (2004, p. 88) conclude from their study of bribes in Peru under Fujimori, "can provide oversight of the government even when the other checks and balances have broken down."

The third dimension of the regime ecology is state capacity, the existence of a professional bureaucracy with the ability to implement policy, including the enforcement of the law, without undue external influence, as well as the wherewithal to do so, including relevant statutes, adequate budgets and personnel, expertise and coordination.

But state capacity can be polyvalent. If, on the one hand, increasing state capacity can improve the accuracy and power of checks and balances and control of corruption, the very fact of such improvement may trigger a response. Realizing that the executive branch may seek to elide their controls, for example, legislatures often respond with a thicket of statutes aimed at curtailing agencies' excessive autonomy (FUKUYAMA, 2014). There may be good reasons to do so - ensuring that laws are faithfully followed, for one. But the very imposition of constraints can hamper a high-capacity agency. In Brazil, for example, in recent years prosecutors and judges have been made subject to an "abuse of authority" law that significantly curtails their freedom of maneuver. Whatever the intention behind such efforts, the net result is that checks and balances make the state more "gummed up" than it was previously, often for fairly long periods of time. The irony, of course, is that it is precisely the strategic deployment of checks and balances that is undermining state agencies' capacity: as capacity increases in one branch, the others respond with attempts to constrain the autonomous deployment of that capacity.

These three aspects of the regime ecology are interdependent. Other things equal, capacity is likely to be weaker in agencies that threaten the dominant regime coalition and stronger in those that serve its purposes. The divergent treatment of military and tax agencies over the past generation in Brazil and the US is a case in point. In the United States, the Pentagon has grown steadily in stature while the IRS has been systematically hobbled, a consequence of the regime coalition's calculus about the relative popularity of each body. By contrast, the picture is nearly the inverse in Brazil, where the Receita Federal has grown in stature as fiscal concerns have dominated politics, while the military seemed systematically constrained (at least until very recently). State capacity, of course, is also transversal, meaning that it is dependent on webs of state agencies. In the absence of a decisive judiciary, the world's best police force may have a difficult time properly tackling corruption; in the absence of effective auditing, similarly, prosecutors may not be supplied with the information needed to actively curb corrupt actors.

\section{CONCLUSION}

We have pointed to several problems that suggest why a more nuanced understanding of the relationship between separation of powers, checks and balances, and control of corruption 
might be desirable: first, the extent to which the concept of checks and balances itself is wobbly; second, the degree to which corruption as understood today is not the same as corruption as understood by Madison and his contemporaries, which suggests that our reasoning about checks and balances' effect on corruption may stem from misconceptions about the role institutional arrangements such as separation of powers were expected to play in liberal democracies; third, to the extent that the overall gist of the concepts can be clarified, the devilish difficulty of evaluating when checks and balances result from separation of powers dynamics, and therefore have the expected causal effect on corruption; fourth, the extent to which checks and balances can be strategically deployed in ways that subvert their democratic purpose and, associated with this, the fact that checks and balances are reliant not just on the institutional framework of separation of powers, but also on the manner by which the formal branches of government are shaped by the broader regime ecology.

As we contemplate how democratic societies might move to a better control of corruption, it becomes clear that the institutional trappings of checks and balances are much less important than the underlying commitment to the norms of democracy itself. Sadly, the cross-cutting cleavages that are so important to making the Madisonian model work without excessive dominance may also neuter anticorruption efforts, by making moves away from the status quo far more difficult than they might be otherwise. Checks and balances, in other words, may permit the imperfect policing of today's regime coalition, and they may improve over time. But they seem unlikely to spur changes that depart significantly from the norms and interests of the core of that coalition, and without changing those norms and interests - whether incrementally or wholesale - checks and balances themselves seem unlikely to generate an equilibrium shift in the control of corruption.

\section{ACKNOWLEDGMENTS}

The authors are grateful to Catarina Barbieri, Kevin Davis, Mariana Mota Prado, Marta Rodriguez Machado, Raquel de Mattos Pimenta, Maria Hermínia Tavares de Almeida, participants in the 2020 conference on Law and Systemic Corruption at the Fundação Getulio Vargas Law School, and the anonymous reviewers for helpful suggestions that greatly improved the final text. Luciano Da Ros further expresses his gratitude for financial support from Brazil's National Council of Scientific and Technological Development (Conselho Nacional do Desenvolvimento Científico e Tecnológico - CNPq). Remaining failures of commission and omission are ours alone. 


\section{REFERENCES}

ACEMOGLU, Daron; ROBINSON, James A. Economic Origins of Dictatorship and Democracy. Cambridge: Cambridge University Press, 2006.

ACEMOGLU, Daron; ROBINSON, James A. Why Nations Fail: The Origins of Power, Prosperity, and Poverty. New York: Crown Publishers, 2012.

ACEMOGLU, Daron; ROBINSON, James A.; TORVIK, Ragnar. Why Do Voters Dismantle Checks and Balances? The Review of Economic Studies, v. 80, n. 3, p. 845-875, 2013.

ALT, James E.; LASSEN, David D. Political and Judicial Checks on Corruption: Evidence from American State Governments. Economics and Politics, v. 20, n. 1, p. 33-61.

ANG, Milena. Corrupting Accountability: Elite Control and Corruption Prosecution in Comparative Perspective. 2017. Unpublished Ph.D. dissertation, Chicago: University of Chicago, 2017.

AMORIM NETO, Octavio. Cabinets and coalitional presidentialism. In: AMES, Barry (ed.). Routledge Handbook of Brazilian Politics. New York: Routledge, 2018.

ANDREWS, Josephine T.; MONTINOLA, Gabriella R. Veto Players and the Rule of Law in Emerging Democracies. Comparative Political Studies, v. 37, n. 1, p. 55-87, 2004.

BACHRACH, Peter; BARATZ, Morton S. Decisions and Nondecisions: An Analytical Framework. American Political Science Review, v. 57, n. 3, p. 632-642, 1963.

BARON, Reuben; KENNY, David. The Moderator-Mediator Variable Distinction in Social Psychological Research: Conceptual, Strategic, and Statistical Considerations. Journal of Personality and Social Psychology, v. 51, p. 1173-1182, 1986.

BERMAN, Sheri. Civil Society and the Collapse of the Weimar Republic. World Politics, v. 49, 1997.

BIRKLAND, Thomas A. An Introduction to the Policy Process: Theories, Concepts, and Models of Public Policy Making. Armonk, New York: M.E. Sharpe, 2001.

BOVENS, Mark. Analysing and assessing accountability: A conceptual framework. European Law Journal, v. 13, n. 4, p. 447-468, 2007. 
BROWN, David S.; TOUCHTON, Michael;WHITFORD, Andrew. Political Polarization as a Constraint on Corruption: A Cross-National Comparison. World Development, v. 39, p. 1516-1529, 2011.

BUTT, Simon; SCHÜTTE, Sofie A. Assessing judicial performance in Indonesia: the court for corruption crimes. Crime, Law and Social Change, v. 62, n. 5, p. 603-619, 2014.

CHAISTY, Paul; CHEESEMAN, Nic; POWER, Timothy J. Coalitional Presidentialism in Comparative Perspective: Minority Presidents in Multiparty Systems. Oxford: Oxford University Press, 2018.

CHANG, Eric C.; GOLDEN, Miriam A. Electoral Systems, District Magnitude and Corruption. British Journal of Political Science, v. 37, p. 115-137, 2006.

COLLIER, David; MAHON Jr., James E. Conceptual "stretching” revisited: adapting categories in comparative analysis. American Political Science Review, v. 87, n. 4, p. 845-855, 1993.

DA ROS, Luciano. Mayors in the Dock: Judicial Responses to Local Corruption in Brazil. Unpublished doctoral dissertation, University of Illinois at Chicago, 2014.

DA ROS, Luciano; INGRAM, Matthew C. Courts, Law, and Judicial Politics. In: AMES, Barry (ed.). Routledge Handbook of Brazilian Politics. New York: Routledge, 2018.

DA ROS, Luciano; TAYLOR, Matthew M. Brazilian Politics on Trial: Corruption and Reform under Democracy. Colorado: Lynne Rienner Publishers, forthcoming.

DAHL, Robert A. A Preface to Democratic Theory. Chicago: University of Chicago Press, 1956.

DAHL, Robert A. Decision-Making in a Democracy: The Supreme Court as a National Policy-Maker. Journal of Public Law, v. 6, p. 279-295, 1957.

DELLA PORTA, Donatella. A judges' revolution? Political corruption and the judiciary in Italy. European Journal of Political Research, v. 39, n. 1, p. 1-21, 2001.

FUKUYAMA, Francis. Political Order and Political Decay: From the Industrial Revolution to the Globalization of Democracy. New York: Farrar, Strauss and Giroux, 2014.

GIBSON, James L.; CALDEIRA, Gregory A. The Legitimacy of Transnational Legal Institutions: Compliance, Support, and the European Court of Justice. American Journal of Political Science, v. 39, p. 459-489, 1995. 
GLAESER, Edward L.; GOLDIN, Claudia D. Corruption and Reform: Lessons from America's Economic History. Chicago: University of Chicago Press, 2006.

HAGGARD, Stephan. Developmental States. Cambridge: Cambridge University Press, 2018.

HAMILTON, Alexander; JAY, John; MADISON, James. The Federalist Papers. New York: New American Library, 1961.

HELLER, William B.; KYRIACOU, Andreas P.; ROCA-SAGALÉS, Oriol. Institutional Checks and Corruption: The Effect of Formal Agenda Access on Governance. European Journal of Political Research, v. 55, p. 681-701, 2016.

HELMKE, Gretchen. Institutions on the Edge: The Origins and Consequences of Institutional Instability in Latin America. Cambridge: Cambridge University Press, 2017.

HOFSTADTER, Richard. The Age of Reform: From Bryan to F.D.R. 1966 ed. New York: Alfred A. Knopf, 1955.

IMAI, Kosuke; KEELE, Luke; TINGLY, Dustin; YAMAMOTO, Teppei. Unpacking the Black Box of Causality: Learning About Causal Mechanisms from Experimental and Observational Studies. American Political Science Review, v. 105, p. 765-789, 2011.

JOHNSTON, Michael. Syndromes of Corruption: Wealth, Power, and Democracy. Cambridge: Cambridge University Press, 2005.

KAPISZEWSKI, Diana. Tactical Balancing: High court decision making on politically crucial cases. Law \& Society Review, v. 45, n. 2, p. 471-506, 2011.

KAPISZEWSKI, Diana; TAYLOR, Matthew M. Compliance: Conceptualizing, Measuring, and Explaining Adherence to Judicial Rulings. Law \& Social Inquiry, v. 38, p. 803-835, 2013.

LAGUNES, Paul F., SVEJNAR Jan (ed.). Corruption and the Lava Jato Scandal in Latin America. New York: Routledge, 2020.

LARKINS, Christopher M. Judicial Independence and Democratization: A Theoretical and Conceptual Analysis. American Journal of Comparative Law, v. 44, p. 605-626, 1996.

LEDERMAN, Daniel; LOAYZA, Norman V.; SOARES, Rodrigo R. Accountability and Corruption: Political Institutions Matter. Economics \& Politics, v. 17, p. 1-35, 2005. 
LIJPHART, Arend. Patterns of Democracy: Government Forms and Performance in Thirty-Six Countries. New Haven: Yale University Press, 1999.

LINDBERG, Staffan I. Mapping Accountability: Core Concept and Subtypes. International Review of Administrative Sciences, v. 79, n. 2, p. 202-226, 2013.

LLANOS, Mariana; LEMOS, Leany Barreiro. Presidential Preferences? The Supreme Federal Tribunal Nominations in Democratic Brazil. Latin American Politics and Society, v. 55, n. 2, p. 77-105, 2013.

MADISON, James. Federalist 51: The Structure of the Government Must Furnish the Proper Checks and Balances Between the Different Departments. In: HAMILTON, Alexander; MADISON, James; JAY, John. The Federalist Papers. New York: New American Library, 1961 [1788].

MAINWARING, Scott. Introduction: Democratic Accountability in Latin America. In: MAINWARING, Scott; WELNA, Christopher (ed.). Democratic Accountability in Latin America. Oxford: Oxford University Press, 2013. p. 3-34.

MANIN, Bernard. Checks, Balances, and Boundaries: The Separation of Powers in the Constitutional Debate of 1787. In: FONTANA, Bianca (ed.). The Invention of the Modern Republic. Cambridge: Cambridge University Press, 1994. p. 27-62.

MANZETTI, Luigi. Accountability and Corruption in Argentina During the Kirchners' Era. Latin American Research Review, v. 49, p. 173-195, 2014.

MARAVALL, José María. The Rule of Law as a PoliticalWeapon. In: MARAVALL, José Maria; PRZEWORSKI, Adam (ed.). Democracy and the Rule of Law. Cambridge: Cambridge University Press, 2003. p. 261-301.

MARSTEINTREDET, Leiv; MALAMUD, Andrés. Coup with Adjectives: Conceptual Stretching or Innovation in Comparative Research? Political Studies, v. 68, n. 4, p. 1014-1035, 2020.

MAZZUCA, Sebastian. Access to Power Versus Exercise of Power: Reconceptualizing the Quality of Democracy in Latin America. Studies in Comparative International Development, v. 45, p. 334-357, 2010.

McMILLAN, John; ZOIDO, Pablo. How to Subvert Democracy: Montesinos in Peru. Journal of Economic Perspectives, v. 18, p. 69-92, 2004.

MECHKOVA, Valeriya; LÜHRMANN, Anna; LINDBERG, Staffan I. The Accountability Sequence: From De-jure to De-facto Constraints on Governments. Studies in Comparative International Development, v. 54, n. 1, p. 40-70, 2019. 
MELO, Marcus André; PEREIRA, Carlos. Making BrazilWork: Checking the President in a Multiparty System. Palgrave: Macmillan, 2013.

MELO, Marcus André; PEREIRA, Carlos; FIGUEIREDO, Carlos Maurício. Political and Institutional Checks on Corruption: Explaining the Performance of Brazilian Audit Institutions. Comparative Political Studies, v. 42, p. 1217-1244, 2009.

NOVAK, William J. A Revisionist History of Regulatory Capture. In: CARPENTER, Daniel; MOSS, David A. (ed.). Preventing Regulatory Capture: Special Interest Influence and How to Limit It. Cambridge: Cambridge University Press, 2013.

O’DONNELL, Guillermo. Horizontal Accountability in New Democracies. Journal of Democracy, v. 9, p. $112-126,1998$.

OLIVEIRA, Vanessa Elias de. Poder Judiciário: árbitro dos conflitos constitucionais entre Estados e União. Lua Nova, v. 78, p. 223-250, 2009.

PANGALANGAN, Raul C. The Philippines' Sandiganbayan: Anti-graft courts and the illusion of selfcontained anti-corruption regimes." In: NICHOLSON, P.; HARDING, A. (ed.). New Courts in Asia. London: Routledge, 2010.

PÉREZ-LIÑÁN, Aníbal. Presidential impeachment and the New Political Instability in Latin America. Cambridge: Cambridge University Press, 2007.

PERSSON, Torsten; ROLAND, Gerard; TABELLINI, Guido. Separation of Powers and Political Accountability. The Quarterly Journal of Economics, v. 112, p. 1163-1202, 1997.

PHILP, Mark. Defining political corruption. Political Studies, v. 45, n. 3, p. 436-462, 1997.

POPE, Jeremy. TI Source Book 2000: Confronting corruption: The elements of a national integrity system. Berlin:Transparency International, 2000.

POPOVA, Maria; POST, Vincent. Prosecuting High-Level Corruption in Eastern Europe. Communist and Post-Communist Studies, v. 51, n. 3, p. 231-244, 2018.

RÍOS-FIGUEROA, Júlio. Justice system institutions and corruption control: evidence from Latin America. Justice System Journal, v. 33, n. 2, p. 195-214, 2012. 
ROSE-ACKERMAN, Susan; PALIFKA, Bonnie. Corruption and Government: Causes, Consequences, and Reform. $2^{\text {nd }}$ ed. Cambridge: Cambridge University Press, 2016.

ROSE-ACKERMAN, Susan; DESIERTO, Diane A.; VOLOSIN, Natalia. Hyper-Presidentialism: Separation of Powers without Checks and Balances in Argentina and the Philippines. Berkeley Journal of International Law, v. 29, n. 1, p. 246-333, 2011.

SALLUM Jr., Brasílio. O impeachment de Fernando Collor: sociologia de uma crise. São Paulo: 34, 2015.

SARTORI, Giovanni. Concept misformation in comparative politics. American Political Science Review, v. 64 , n. 4, p. 1033-1053, 1970.

SHAPIRO, Martin. Courts: A Comparative and Political Analysis. Chicago: University of Chicago Press, 1981.

SIMS, Kimberly. Judges without Borders? Transnational Networks of Anti-Corruption Prosecuting Judges in Europe. Unpublished doctoral dissertation, Northwestern University, 2011.

SUNSTEIN, Cass R. Impeaching the President. University of Pennsylvania Law Review, v. 147, n. 2, p. 279 $315,1998$.

TSEBELIS, George. Decision Making in Political Systems: Veto Players in Presidentialism, Parliamentarism, Multicameralism, and Multipartyism. British Journal of Political Science, v. 25, p. 289-325, 1995.

TSEBELIS, George. Veto Players and Institutional Analysis. Governance, v. 13, p. 441-474, 2000.

WALLIS, John J. The Concept of Systematic Corruption in American Political and Economic History. NBER Working Papers 10952, 2004.

WARREN, Mark E. What does corruption mean in a democracy? American Journal of Political Science, v. 48, n. 2, p. 328-343, 2004.

\section{HOW TO QUOTE THIS ARTICLE:}

DA ROS, Luciano; TAYLOR, Matthew M. Checks and Balances: The Concept and Its Implications for Corruption. Revista Direito GV, v. 17, n. 2, maio/ago. 2021, e2120. https://doi.org/10.1590/ 2317-6172202120
Luciano Da Ros

Adjunct Professor of the Department of Sociology and Political Science at the Federal University of Santa Catarina. His articles haVe beEn PUblished IN DADOS, Brazilian Political Science Review and Revista de Sociologia e Política. daros.luclagmail.com 
Matthew M. Taylor

Associate Professor of the School of INTERNATIONAL SERVICE AT THE AMERICAN UNIVERSITY. HIS MOST RECENT BOOK IS Decadent Developmentalism: The Political Economy of Democratic Brazil (CAMBridge University Press, 2020).

mtayloraamerican.edu 